\title{
Temporal and spatial variability of phytoplankton pigment concentrations in the Indian Ocean, derived from the CZCS time series images
}

\author{
Variabilidad temporal y espacial de las concentraciones de pigmentos fitoplanctónicos \\ en el Océano Î́ndico, a partir de imágenes CZCS
}

\author{
Abul B.M. Alauddin Talukder \\ School of Biological Science \\ Flinders University of South Australia \\ GPO Box 5100 \\ Adelaide, Australia \\ E-mail: talu0001@flinders.edu.au
}

Recibido en septiembre de 2003; aceptado en enero de 2005

\begin{abstract}
A total of 93 monthly global composite remotely sensed ocean color images from the Coastal Zone Color Scanner (CZCS) on board the Nimbus-7 satellite were extracted for the Indian Ocean region $\left(35^{\circ} \mathrm{N}-55^{\circ} \mathrm{S} ; 30-120^{\circ} \mathrm{E}\right)$ to examine the seasonal variations in phytoplankton pigment concentrations, resulting from large-scale changes in physical oceanographic processes. The CZCS data sets were analyzed with the PC-SEAPAK software, and revealed large phytoplankton blooms in the northwest Arabian Sea and off the Somali coast. The blooms were triggered by wind-driven upwelling during the southwest monsoonal months of August and September. In the northern Arabian Sea, phytoplankton blooms, detected from January to March, appeared to be associated with nutrient enhancement resulting from winter convective mixing. In the Bay of Bengal, higher pigment concentrations were confined to the coastal regions but varied only marginally between seasons both in the coastal and offshore regions. Phytoplankton pigment concentrations were consistently low in the open Indian Ocean. Analysis of pigment concentrations extracted from the monthly-accumulated images revealed that the Arabian Sea sustained a greater biomass of phytoplankton compared with any other region of the Indian Ocean. Overall, the coastal regions of the Indian Ocean are richer in phytoplankton pigment than the open Indian Ocean. The number of images in individual areas was highly variable throughout the region due to varying cloud cover.
\end{abstract}

Key words: phytoplankton pigment concentration, monsoon, Indian Ocean, Coastal Zone Color Scanner.

\section{Resumen}

Se obtuvieron 93 imágenes mensuales compuetas del sensor remoto de color del mar Coastal Zone Color Scanner (CZCS), a bordo del satélite Nimbus-7, para la región del Océano Índico $\left(35^{\circ} \mathrm{N}-55^{\circ} \mathrm{S}\right.$; $\left.30-120^{\circ} \mathrm{E}\right)$, con el fin de determinar las variaciones estacionales de las concentraciones de pigmentos fitoplanctónicos producidas por cambios a gran escala en los procesos oceanográficos físicos. Los datos del CZCS fueron analizados usando la paquetería PC-SEAPAK y mostraron florecimientos extensos de fitoplancton en el noroeste del Mar Arábigo y frente a la costa de Somalia. Los florecimientos resultaron de surgencias inducidas por el viento durante los meses del monzón del suroeste de agosto y septiembre. En el norte del Mar Arábigo, los florecimientos fitoplanctónicos, detectados entre enero y marzo, parecen estar asociados con el enriquecimiento de nutrientes debido a la mezcla convectiva invernal. En la Bahía de Bengala, las mayores concentraciones de pigmentos se limitaron a las regiones costeras, variando sólo marginalmente entre estaciones del año tanto en las áreas costeras como mar adentro. Las concentraciones de pigmentos fitoplanctónicos fueron consistentemente bajas en el Océano Índico abierto. El análisis de las concentraciones de pigmentos obtenidas de las imágenes acumuladas mensualmente mostró que el Mar Arábigo sostiene una biomasa mayor de fitoplancton en comparación con otras regiones del Océano Índico. En general, las regiones costeras del Océano Índico son más ricas en pigmentos fitoplanctónicos que las oceánicas. El número de imágenes de áreas específicas fue altamente variable en toda la región debido a la cambiante nubosidad.

Palabras clave: concentración de pigmentos fitoplanctónicos, monzón, Océano Índico, sensor CZCS.

\section{Introduction}

In the marine environment, pigments provides an index of phytoplankton biomass irrespective of species composition and size (Esais, 1980; Yentsch, 1983; McClain et al., 1990). The

\section{Introducción}

En el ambiente marino, los pigmentos que contiene el fitoplancton proporcionan un índice de la biomasa de estos organismos independientemente de las especie y sus tamaños 
amount of back-scattered solar radiation reradiated from just beneath the sea surface is the best measure of this index (Hovis et al., 1980). The Coastal Zone Color Scanner (CZCS) on board the Nimbus-7 satellite, launched on 23 October 1978 (Hovis et al., 1980) and operated until June 1986, accumulated more than 68,000 images (Feldman et al., 1989). Remote sensing of ocean color is an important tool for recording regional and global scale phytoplankton pigment concentrations (Gordon et al., 1980; Hovis et al., 1980; Yentsch, 1983; Gordon and Morel, 1983), marine primary production (Platt and Sathyendranath, 1988; Sathyendranath et al., 1991) and surface patterns of the oceans (Barnard et al., 1997).

The monsoonal wind system of the Indian Ocean causes semi-annual reversal of the surface currents in the Bay of Bengal and Arabian Sea. Wyrtki (1973) stated that the Indian Ocean region is a classic example of atmospheric forcing of upper ocean circulation. In January and February, the winds bring cool dense air to India from the Asian land mass; this flow of air is the northeast (NE) monsoon. The southwest (SW) monsoon blowing more or less parallel to the Somali and Arabian coasts commences in May/June, reaches a peak in July/August, and fades away in September/October. Both monsoons change the oceanography of the Arabian Sea (Wyrtki, 1971; Krey and Babenered, 1976). The distribution of chlorophyll $a$ in the Indian Ocean region was reported (Qasim, 1978) using data from the International Indian Ocean Expedition. Global ocean seasonal pigment concentrations have been analyzed by Yoder et al. (1993) and Banse and English (1994). Yet the whole Indian Ocean remains one of the least studied areas in the world oceans with relatively few reports available on the distribution of phytoplankton pigment concentrations. The CZCS pigment concentration data of the Arabian Sea have been used by Banse and McClain (1986), Banse (1987), and Banse and English (2000).

The purpose of this study was to investigate the temporal variability of the phytoplankton pigment concentrations in the Indian Ocean, using ocean color imagery. Image count data during 93 months were also considered for the interpretation of pigment pattern distribution.

\section{Study area}

The area of the Indian Ocean (fig. 1), including the Red Sea and the Persian Gulf, is about $49 \times 10^{6} \mathrm{~km}^{2}$. The Indian Peninsula divides the Indian Ocean into the Bay of Bengal and the Arabian Sea, which is extended to the north by the Gulf of Oman and the Persian Gulf and to the west by the Gulf of Aden and the Red Sea. The Bay of Bengal, of about $2.2 \times 10^{6} \mathrm{~km}^{2}$ and lying between the Indian Peninsula and Myanmar, is characterized by complex current systems. It is bordered on the north by the deltaic regions of the Ganges and Brahmaputra river systems and experiences surface stratification due to the influx of fresh water from these river systems. According to
(Esais, 1980; Yentsch, 1983; McClain et al., 1990). La cantidad de retrodispersión solar retransmitida desde justo debajo de la superficie oceánica es la mejor medida de este índice (Hovis et al., 1980). El sensor de color del mar Coastal Zone Color Scanner (CZCS) a bordo del satélite Nimbus-7, lanzado el 23 de octubre de 1978 (Hovis et al., 1980) y operado hasta junio de 1986, acumuló más de 68,000 imágenes (Feldman et al., 1989). El uso de sensores remotos de color del mar constituye una herramienta importante para registrar, a nivel regional y global, las concentraciones de pigmentos fitoplanctónicos (Gordon et al., 1980; Hovis et al., 1980; Yentsch, 1983; Gordon y Morel, 1983), la producción primaria (Platt y Sathyendranath, 1988; Sathyendranath et al., 1991) y los patrones superficiales de los océanos (Barnard et al., 1997).

El sistema de vientos monzónicos sobre el Océano Índico causa una inversión semianual de las corrientes superficiales de la Bahía de Bengala y el Mar Arábigo. Según Wyrtki (1973), la región del Océano Î́ndico es un ejemplo clásico del forzamiento atmosférico de la circulación en la capa superior del océano. En enero y febrero los vientos transportan aire frío y denso interior del continente asiático hacia la India; este flujo de aire es el monzón del noreste (NE). El monzón del suroeste (SW) sopla más o menos paralelo a las costas somalíes y árabes, inicia en mayo/junio, se intensifica en julio/agosto y se desvanece en septiembre/octubre. Ambos monzones modifican la oceanografía del Mar Arábigo (Wyrtki, 1971; Krey y Babenered, 1976). Qasim (1978) determinó la distribución de clorofila $a$ en la región del Índico usando datos de la Expedición Internacional del Océano Índico, mientras que Yoder et al. (1993) y Banse e English (1994) analizaron las concentraciones estacionales de pigmentos; sin embargo, esta región sigue siendo una de las áreas menos estudiadas de los océanos mundiales, existiendo relativamente pocos registros de la distribución de las concentraciones de pigmentos fitoplanctónicos. Los datos de la concentración de pigmentos del CZCS para el Mar Arábigo han sido utilizados por Banse y McClain (1986), Banse (1987) y Banse e English (2000).

El objetivo de este estudio fue investigar la variabilidad temporal de las concentraciones de pigmentos fitoplanctónicos en el Océano Índico mediante imágenes de color del mar. Para determinar el patrón de distribución de pigmentos también se consideró el número de imágenes interpretadas durante los 93 meses.

\section{Área de estudio}

El área del Océano Índico (fig. 1), incluyendo el Mar Rojo y el Golfo Pérsico, es de alrededor de $49 \times 10^{6} \mathrm{~km}^{2}$. La Península Índica divide al Océano Índico en la Bahía de Bengala y el Mar Arábigo, el cual se extiende al norte hacia los golfos de Omán y Pérsico y al oeste hacia el Golfo de Adén y el Mar Rojo. La Bahía de Bengala, de unos $2.2 \times 10^{6} \mathrm{~km}^{2}$, se localiza entre la península índica y Birmania (Myanmar) y se caracteriza por un complejo sistema de corrientes; es delimitada al norte por las regiones deltaicas de los ríos Ganges y 


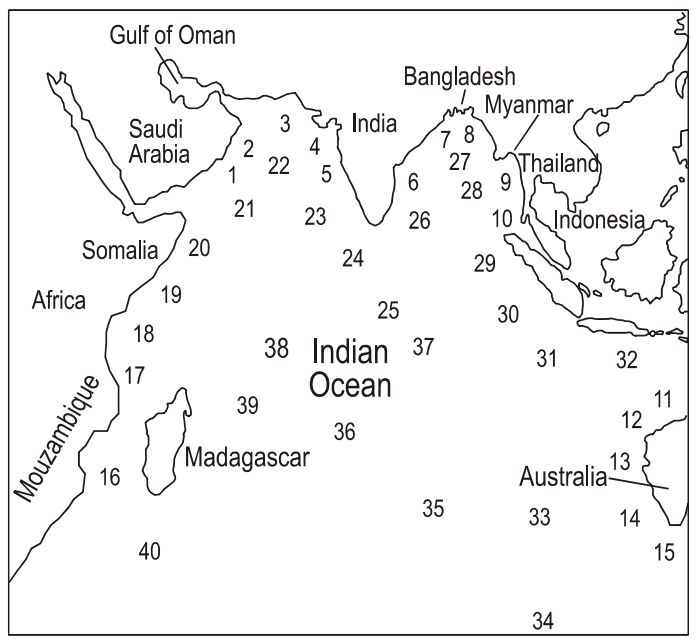

Figure 1. Location of the study area and the 40 stations selected. Stations 1-20 are located in the coastal region and stations $21-40$ in the open ocean region.

Figura 1. Localización del área de estudio y de las 40 estaciones seleccionadas. Las estaciones 1-20 se localizan en la región costera y las estaciones 21-40 en el mar abierto.

UNESCO (1988), the combined annual discharge from the Ganges, Brahmaputra, Irrawady and Godavari rivers exceeds $1.5 \times 10^{12} \mathrm{~m}^{3}$.

\section{Methods}

The CZCS global data sets were obtained from NASA's Goddard Space Flight Centre, as level 3 global CZCS processing data and processed on dedicated computer facilities at the Institute of Hydrospheric and Atmospheric Sciences, Nagoya University, Japan. Time series data sets of pigment concentrations from October 1978 to June 1986 (93 months) were analyzed by an image analysis system, PC-SEAPAK software (Darzi et al., 1989). Monthly global composite images were used in this study and subsets of data for the Indian Ocean region $\left(35^{\circ} \mathrm{N}-55^{\circ} \mathrm{S} ; 30^{\circ}-120^{\circ} \mathrm{E}\right)$ were extracted from the global CZCS data using the Pstimg program. The extracted monthly images of phytoplankton pigment concentration and image count data were accumulated on disk, and the software programs Meanf and Addf (Darzi et al., 1989) were used to calculate the mean monthly pigment and image counts. Forty positions at different latitudes and longitudes (see fig. 1; table 1) were selected over the 12 interpolated images of January through December (fig. 2) using the Read program to calculate the pigment concentrations. Stations 1-20 and 21-40 were selected in the coastal region and open ocean region, respectively, to estimate pigment concentrations. Stations in the Arabian Sea are numbered 1-5 and 21-24, those in the Bay of Bengal are numbered 6-10 and 26-29, and those in open ocean regions are numbered 25, 31-33 and 35-39 (fig. 1; table 1).
Brahmaputra y está sujeta a estratificación superficial debido a la entrada del agua dulce de estos sistemas fluviales. Según la UNESCO (1988), la descarga anual combinada de los ríos Ganges, Brahmaputra, Irrawady y Godavari supera los $1.5 \times$ $10^{12} \mathrm{~m}^{3}$.

\section{Métodos}

Los conjuntos de datos del CZCS fueron obtenidos del centro espacial Goddard de la NASA, como datos globales de nivel 3, y fueron procesados en un centro de cómputo especializado en el Instituto de Ciencias Hidrosféricas y Atmosféricas de la Universidad de Nagoya, Japón. Los datos de la serie de tiempo de las concentraciones de pigmentos de octubre de 1978 a junio de 1986 (93 meses) se analizaron mediante el sistema de análisis de imágenes PC-SEAPAK (Darzi et al., 1989). En este estudio se utilizaron imágenes mensuales compuestas, y a partir de los datos globales del CZCS se obtuvieron sub- series de datos para la región del Océano Índico $\left(35^{\circ} \mathrm{N}-55^{\circ} \mathrm{S} ; 30^{\circ}-120^{\circ} \mathrm{E}\right)$, utilizando el programa Pstimg. Las imágenes mensuales de la concentración de pigmentos fitoplanctónicos que se obtuvieron fueron almacenadas en disco, así como el número de imágenes consideradas, utlizando los programas de cómputo Meanf y Addf (Darzi et al., 1989) para calcular los promedios mensuales de concentración de pigmentos y número de imágenes. Se seleccionaron 40 posiciones (estaciones) a diferentes latitudes y longitudes (ver fig. 1; tabla 1) sobre 12 imágenes interpoladas de enero a diciembre (fig. 2) utilizando el programa Read para calcular las concentraciones de pigmentos. Las estaciones 1-20 se localizan en la región costera y las estaciones 21-40 en mar abierto. Las estaciones 1-5 y 21-24 corresponden al Mar Arábigo, las estaciones 6-10 y 26-29 a la Bahía de Bengala, y las estaciones 25, 31-33 y 35-39 a regiones de mar abierto (fig. 1; tabla 1 ).

\section{Resultados y discusión}

La serie de tiempo de 93 meses de datos del CZCS (fig. 2) muestra diferencias significativas en los procesos físicos oceanográficos en el Océano Índico. Se aprecian florecimientos extensos de fitoplancton en el noroeste del Mar Arábigo y frente a la costa de Somalia. Éstos aparentemente son el resultado de surgencias inducidas por el viento durante los meses del monzón SW de agosto y septiembre, e indican que los efectos biológicos de las surgencias fueron considerables a lo largo de la costa de Somalia y en el noroeste del Mar Arábigo. En el norte del Mar Arábigo, los florecimientos fitoplanctónicos detectados de enero a marzo (monzón NE) están asociados con el enriquecimiento de nutrientes debido a la mezcla convectiva de invierno. Durante el monzón NE (noviembre/diciembre a marzo/abril), aire continental frío y seco es llevado al norte del Mar Arábigo por los vientos alisios predominantes del noreste, los cuales intensifican la evaporación y producen enfriamiento de la superficie (Prasanna-Kumar y Prasad, 1996) y un 

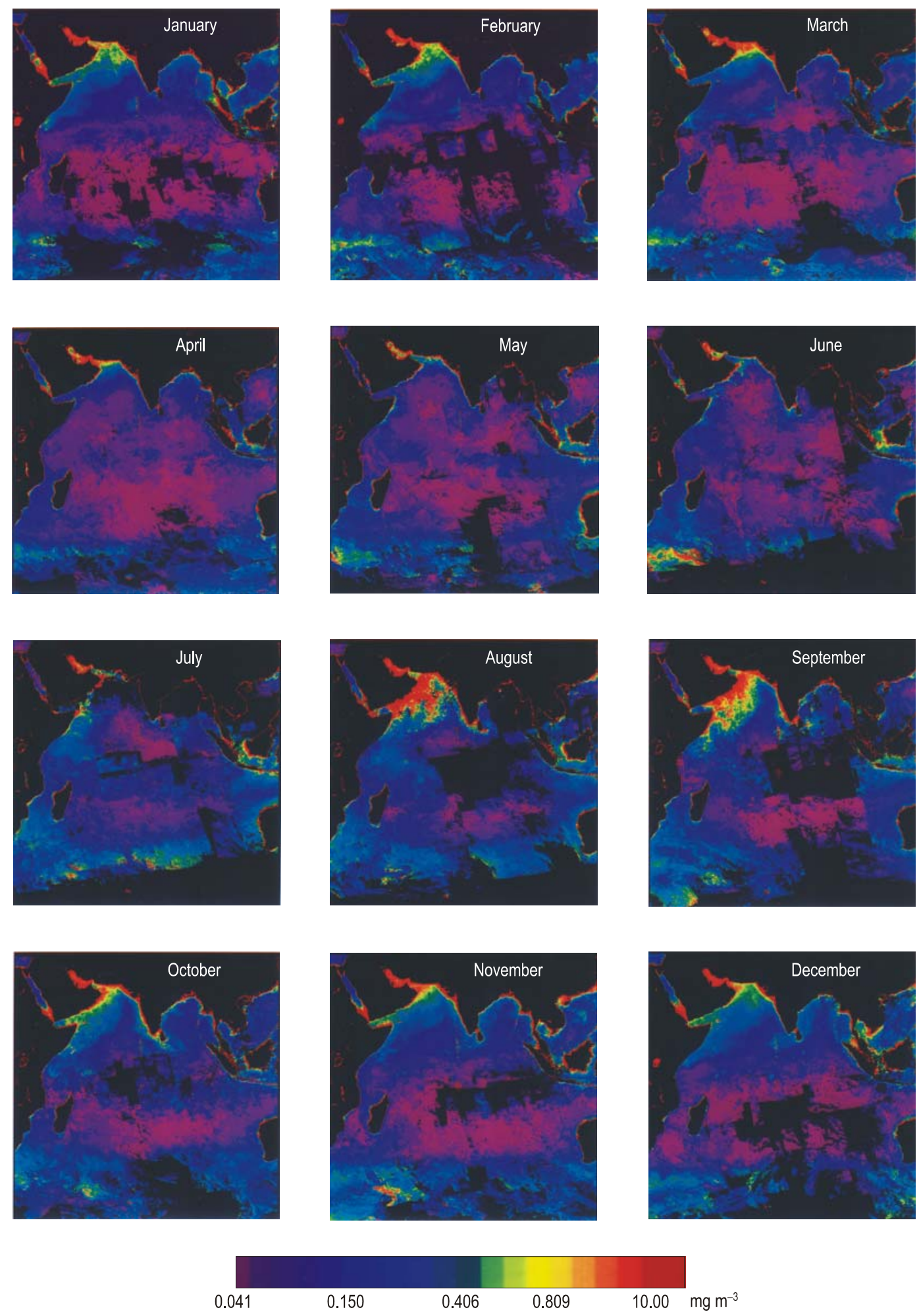

Figure 2. Time series for the 93-month period (October 1978 to June 1986) of the monthly mean seasonal distribution of surface pigment concentrations in the Indian Ocean region. The color bar goes from violet, for low concentrations, to red, for high concentrations.

Figura 2. Serie de tiempo para el periodo de 93 meses (octubre de 1978 a junio de 1986) de la distribución estacional media mensual de las concentraciones superficiales de pigmentos en la región del Océano Índico. La barra de color va de violeta, para concentraciones bajas, a rojo, para concentraciones altas. 
Table 1. Latitude and longitude for the 40 locations selected over the 12 interpolated time series images (fig. 2) for the extraction of phytoplankton pigment concentration.

Tabla 1. Latitud y longitud de las 40 estaciones seleccionadas de la serie de tiempo de las 12 imágenes interpoladas (fig. 2) para la extracción de la concentración de pigmentos fitoplanctónicos.

\begin{tabular}{|c|c|c|c|c|c|}
\hline Station & Lat. & Long. & Station & Lat. & Long. \\
\hline 1 & $15^{\circ} 55^{\prime} \mathrm{N}$ & $56^{\circ} 65^{\prime} \mathrm{E}$ & 21 & $7^{\circ} 82^{\prime} \mathrm{N}$ & $58^{\circ} 94^{\prime} \mathrm{E}$ \\
\hline 2 & $20^{\circ} 65^{\prime} \mathrm{N}$ & $59^{\circ} 99^{\prime} \mathrm{E}$ & 22 & $15^{\circ} 02^{\prime} \mathrm{N}$ & $63^{\circ} 34^{\prime} \mathrm{E}$ \\
\hline 3 & $25^{\circ} 04^{\prime} \mathrm{N}$ & $62^{\circ} 99^{\prime} \mathrm{E}$ & 23 & $13^{\circ} 09^{\prime} \mathrm{N}$ & $69^{\circ} 33^{\prime} \mathrm{E}$ \\
\hline 4 & $23^{\circ} 81^{\prime} \mathrm{N}$ & $66^{\circ} 86^{\prime} \mathrm{E}$ & 24 & $8^{\circ} 17^{\prime} \mathrm{N}$ & $72^{\circ} 05^{\prime} \mathrm{E}$ \\
\hline 5 & $15^{\circ} 73^{\prime} \mathrm{N}$ & $72^{\circ} 05^{\prime} \mathrm{E}$ & 25 & $1^{\circ} 84^{\prime} \mathrm{N}$ & $78^{\circ} 66^{\prime} \mathrm{E}$ \\
\hline 6 & $12^{\circ} 56^{\prime} \mathrm{N}$ & $80^{\circ} 95^{\prime} \mathrm{E}$ & 26 & $12^{\circ} 91^{\prime} \mathrm{N}$ & $85^{\circ} 01^{\prime} \mathrm{E}$ \\
\hline 7 & $18^{\circ} 19^{\prime} \mathrm{N}$ & $84^{\circ} 83^{\prime} \mathrm{E}$ & 27 & $15^{\circ} 73^{\prime} \mathrm{N}$ & $89^{\circ} 76^{\prime} \mathrm{E}$ \\
\hline 8 & $18^{\circ} 01^{\prime} \mathrm{N}$ & $93^{\circ} 63^{\prime} \mathrm{E}$ & 28 & $10^{\circ} 63^{\prime} \mathrm{N}$ & $94^{\circ} 34^{\prime} \mathrm{E}$ \\
\hline 9 & $14^{\circ} 05^{\prime} \mathrm{N}$ & $97^{\circ} 16^{\prime} \mathrm{E}$ & 29 & $2^{\circ} 72^{\prime} \mathrm{N}$ & $91^{\circ} 07^{\prime} \mathrm{E}$ \\
\hline 10 & $6^{\circ} 59^{\prime} \mathrm{N}$ & $98^{\circ} 74^{\prime} \mathrm{E}$ & 30 & $5^{\circ} 36^{\prime} \mathrm{S}$ & $95^{\circ} 04^{\prime} \mathrm{E}$ \\
\hline 11 & $18^{\circ} 89^{\prime} \mathrm{S}$ & $117^{\circ} 94^{\prime} \mathrm{E}$ & 31 & $11^{\circ} 86^{\prime} S$ & $100^{\circ} 86^{\prime} \mathrm{E}$ \\
\hline 12 & $20^{\circ} 65^{\prime} \mathrm{S}$ & $114^{\circ} 95^{\prime} \mathrm{E}$ & 32 & $14^{\circ} 32^{\prime} \mathrm{S}$ & $112^{\circ} 03^{\prime} \mathrm{E}$ \\
\hline 13 & $25^{\circ} 75^{\prime} \mathrm{S}$ & $112^{\circ} 83^{\prime} \mathrm{E}$ & 33 & $29^{\circ} 97^{\prime} \mathrm{S}$ & $107^{\circ} 09^{\prime} \mathrm{E}$ \\
\hline 14 & $31^{\circ} 02^{\prime} \mathrm{S}$ & $114^{\circ} 95^{\prime} \mathrm{E}$ & 34 & $47^{\circ} 54^{\prime} \mathrm{S}$ & $113^{\circ} 18^{\prime} \mathrm{E}$ \\
\hline 15 & $35^{\circ} 24^{\prime} \mathrm{S}$ & $116^{\circ} 71^{\prime} \mathrm{E}$ & 35 & $29^{\circ} 61^{\prime} \mathrm{S}$ & $94^{\circ} 87^{\prime} \mathrm{E}$ \\
\hline 16 & $25^{\circ} 22^{\prime} \mathrm{S}$ & $34^{\circ} 81^{\prime} \mathrm{E}$ & 36 & $16^{\circ} 78^{\prime} \mathrm{S}$ & $75^{\circ} 49^{\prime} \mathrm{E}$ \\
\hline 17 & $7^{\circ} 47^{\prime} \mathrm{S}$ & $39^{\circ} 39^{\prime} \mathrm{E}$ & 37 & $5^{\circ} 53^{\prime} \mathrm{S}$ & $85^{\circ} 53^{\prime} \mathrm{E}$ \\
\hline 18 & $1^{\circ} 14^{\prime} \mathrm{S}$ & $42^{\circ} 73^{\prime} \mathrm{E}$ & 38 & $3^{\circ} 06^{\prime} S$ & $63^{\circ} 69^{\prime} \mathrm{E}$ \\
\hline 19 & $2^{\circ} 09^{\prime} \mathrm{N}$ & $47^{\circ} 49^{\prime} \mathrm{E}$ & 39 & $15^{\circ} 73^{\prime} \mathrm{S}$ & $54^{\circ} 18^{\prime} \mathrm{E}$ \\
\hline 20 & $10^{\circ} 28^{\prime} \mathrm{N}$ & $51^{\circ} 54^{\prime} \mathrm{E}$ & 40 & $32^{\circ} 43^{\prime} \mathrm{S}$ & $44^{\circ} 85^{\prime} \mathrm{E}$ \\
\hline
\end{tabular}

\section{Results and discussion}

The 93-month time series of CZCS pigment concentration data (fig. 2) shows large-scale differences in physical oceanographic processes in the Indian Ocean. Large-scale phytoplankton blooms are apparent in the northwest Arabian Sea and off the Somali coast. These were apparently triggered by wind-driven upwelling during the SW monsoonal months of August and September, which also show that the biological effects of upwelling were greatly pronounced all along the Somali coast and northwest Arabian Sea. In the northern Arabian Sea, phytoplankton blooms, detected from January to March (NE monsoon), are associated with nutrient enhancement resulting from winter convective mixing. During the NE monsoon (November/December to March/April) cool dry continental air is brought into the northern Arabian Sea by the prevailing NE trade winds that intensify evaporation, leading to surface cooling (Prasanna-Kumar and Prasad, 1996) and the subsequent upward transport of nutrients from the subsecuente transporte hacia la superficie de nutrientes de la región de la termoclina. La inyección de nutrientes a las capas superiores de la columna de agua genera la producción primaria en el Mar Arábigo (Madhupratap et al., 2000). Durante el monzón invernal los pigmentos superficiales presentaron un amplio intervalo, con valores de 0.904 a $1.26 \mathrm{mg} \mathrm{m}^{-3}$ en la región costera y de 0.07 a $0.138 \mathrm{mg} \mathrm{m}^{-3}$ en la costa oriental de la India. Banse y McClain (1986) identificaron florecimientos extensos de fitoplancton en los meses de invierno de 1979/80 en el norte del Mar Arábigo. Las mayores concentraciones de pigmentos estuvieron confinadas a las regiones costeras y variaron marginalmente entre estaciones del año, tanto en la región costera como en la oceánica de la Bahía de Bengala. Las concentraciones de pigmentos fitoplanctónicos fueron bajas en Bahía de Bengala durante el monzón NE, pero incrementaron durante el monzón SW. Chauhan et al. (2001) mostraron que las aguas oceánicas de la Bahía de Bengala son oligotróficas, con concentraciones de clorofila $a$ menores que $0.03 \mathrm{mg} \mathrm{m}^{-3}$. Estos autores también mencionaron una gran pluma de río que se extiende al mar abierto entre enero y marzo de 2000. Se ha detectado una región de surgencias en la costa sur de Sri Lanka y en la costa oeste de la India de agosto a octubre. Durante este tiempo las corrientes superficiales fluyen hacia el sur y acarrean nutrientes de la costa oeste de la India hacia la costa sur de Sri Lanka. Las surgencias inducidas por el viento y una serie de tormentas ciclónicas transportan nutrientes a la zona bien mezclada y a la zona superior de la columna de agua. De enero a marzo la costa sur de Sri Lanka está sujeta a enfriamiento y densificación, produciendo mezcla convectiva y una inyección de nutrientes a la capa superficial del océano. Con el inicio del monzón NE las corrientes superficiales invierten su dirección y fluyen hacia el norte, llevando bajas concentraciones de nutrientes de la región ecuatorial, y generan las bajas concentraciones de pigmentos de la costa sur de Sri Lanka.

La ausencia de surgencias a gran escala fue evidente en la plataforma continental de Australia occidental, con bajas concentraciones de pigmentos debidas a la Corriente Leeuwin, la cual transporta agua más templada y fluye intensamente durante el invierno (ver CSIRO, http://www.per.marine. csiro.au). No obstante, las concentraciones de pigmentos incrementaron en mayo y alcanzaron un máximo de $0.5 \mathrm{mg} \mathrm{m}^{-3}$ en julio y agosto, lo cual indica surgencias en la costa australiana occidental.

Un resumen de la variación mensual de los datos de concentración de pigmentos que se obtuvieron de las imágenes promediadas (tabla 2) muestra que las regiones costeras del Índico son más ricas en pigmentos fitoplanctónicos que el mar abierto. Las desviaciones estándar de las concentraciones medias de pigmentos en la región costera frecuentemente son mayores que las medias, debido a la gran variabilidad entre sitios. La región costera del Mar Arábigo muestra una concentración de pigmentos mucho mayor que cualquier otra región del Océano Índico. La figura 3 es un ejemplo de la variación de las concentraciones de pigmentos en junio y noviembre en diferentes estaciones de la región costera, y las concentraciones 
thermocline region. Nutrient injection into the upper layers of the water column triggers the primary productivity in the Arabian Sea (Madhupratap et al., 2000). During the winter monsoon the surface pigments exhibited a large range, from 0.904 to $1.26 \mathrm{mg} \mathrm{m}^{-3}$ in the coastal region and from 0.07 to $0.138 \mathrm{mg} \mathrm{m}^{-3}$ on the east coast of India. Banse and McClain (1986) identified large-scale phytoplankton blooms in the winter months of 1979/80 in the northern Arabian Sea. Higher pigment concentrations were confined to the coastal regions and varied marginally over seasons, both in the coastal and offshore region of the Bay of Bengal. Phytoplankton pigment concentrations were low in the Bay of Bengal during the NE monsoon, but increased during the SW monsoon. Chauhan et al. (2001) reported that open ocean waters of the Bay of the Bengal are oligotrophic, with chlorophyll $a$ concentrations less than $0.03 \mathrm{mg} \mathrm{m}^{-3}$. The authors also reported a large-scale river plume extending into the open ocean in the months of January to March 2000. A region of upwelling has been detected on the south coast of Sri Lanka and the west coast of India from August to October. During this time surface currents move southward carrying high nutrients from the west coast of India to the south coast of Sri Lanka. Wind-driven upwelling and a series of cyclonic storms transport nutrients to the well-mixed zone and into the upper layer of the water column. From January to March the south coast of Sri Lanka experiences cooling and densification, leading to convective mixing and an injection of nutrients into the surface water layer. With the onset of the NE monsoon the surface currents reverse their direction of flow northwards, carrying low nutrients from the equatorial region, and produce the low pigment concentration on the south coast of Sri Lanka.

An absence of large-scale upwelling was evident on the western Australian continental shelf, with low pigment concentrations because of the Leeuwin Current, which carries warmer water and flows strongly during the winter (see CSIRO at http:/ /www.per.marine.csiro.au). However, pigment concentrations increased in May and reached a maximum concentration of 0.5 $\mathrm{mg} \mathrm{m}^{-3}$ by July and August, indicative of upwelling on the western Australian coast.

A summary of the monthly variation in pigment concentration data extracted from the average images (table 2) reveals that the coastal regions of the Indian Ocean are richer in phytoplankton pigment than the open Indian Ocean. The standard deviations of mean pigment concentrations in the coastal region are often higher than the means, due to high variability between sites. The coastal region of the Arabian Sea has a much higher pigment concentration than any other region of the Indian Ocean. Figure 3 is an example of the variation in pigment concentration data in June and November at different stations in the coastal region of the Indian Ocean. Pigment concentrations in the Arabian Sea (stations 1-5) are generally higher compared with other regions of the Indian Ocean.

Monthly time series of the 93-month image count data (fig. 4) show that the number of images in individual months is
Table 2. Time series for the 93-month period (October 1978 to June 1986) of the monthly seasonal variation (mean $[\mathrm{AV}] \pm$ standard deviation $[\mathrm{SD}]$ ) of phytoplankton pigment $(\mathrm{Chl}=$ chlorophyll) concentration in the coastal and open ocean regions of the Indian Ocean. Pigment concentrations were extracted over the 12 interpolated time series average images (fig. 2). The positions are located in figure 1 and table 1.

Tabla 2. Serie de tiempo para el periodo de 93 meses (octubre de 1978 a junio de 1986) de la variación estacional mensual (media [AV] \pm desviación estándar [SD]) de la concentración de pigmentos fitoplanctónicos (Chl = clorofila) en la región costera y el mar abierto del Océano Índico. Las concentraciones de pigmentos fueron extraidas de la serie de tiempo del promedio de las 12 imágenes interpoladas (fig. 2). Las posiciones se encuentran en la figura 1 y tabla 1.

\begin{tabular}{lccc}
\hline Images & $\begin{array}{c}\text { Coastal region } \\
\text { Chl concentration } \\
\left(\mathrm{mg} \mathrm{m}^{-3}\right)\end{array}$ & & $\begin{array}{c}\text { Open ocean region } \\
\text { Chl concentration } \\
\left(\mathrm{mg} \mathrm{m}^{-3}\right)\end{array}$ \\
\cline { 2 - 3 } January & $\mathrm{AV} \pm \mathrm{SD}$ & $\mathrm{AV} \pm \mathrm{SD}$ \\
February & $0.531 \pm 0.433 \pm 0.372$ & & $0.107 \pm 0.069$ \\
March & $0.785 \pm 1.083$ & & $0.078 \pm 0.037$ \\
April & $0.413 \pm 0.865$ & & $0.073 \pm 0.031$ \\
May & $0.521 \pm 0.755$ & & $0.073 \pm 0.031$ \\
June & $0.335 \pm 0.435$ & & $0.072 \pm 0.031$ \\
July & $0.703 \pm 0.907$ & & $0.122 \pm 0.060$ \\
August & $1.190 \pm 1.380$ & & $0.230 \pm 0.330$ \\
September & $1.920 \pm 1.660$ & & $0.237 \pm 0.298$ \\
October & $0.819 \pm 1.193$ & & $0.126 \pm 0.062$ \\
November & $0.555 \pm 0.759$ & $0.115 \pm 0.047$ \\
December & $0.511 \pm 0.534$ & $0.108 \pm 0.051$ \\
Annual & $0.728 \pm 0.387$ & $0.120 \pm 0.100$ \\
\hline
\end{tabular}

de pigmentos del Mar Arábigo (estaciones 1-5) son mayores en comparación con otras regiones del Índico.

La serie de tiempo del conteo de imágenes en 93 meses (fig. 4) muestra que el número de imágenes consideradas en cada mes fue variable debido a la nubosidad cambiante nubosidad y a los diferentes objetivos para los que era utilizado el Nimbus-7. La comparación del promedio de imágenes utilizadas para cada mes en las regiones costeras y oceánicas (fig. 5) muestra que el número de imágenes de la región costera fue mayor que el de las de mar abierto, y que el monzón NE está relativamente libre de nubes en relación con el monzón SW. Los números de imágenes para el Mar Arábigo, la Bahía de Bengala y la región ecuatorial del Océano Índico (fig. 6) indican que el Mar Arábigo contó con el mayor número de imágenes, seguido por la Bahía de Bengala y luego la región ecuatorial del Índico; sin embargo, la cobertura de nubes sobre el Mar Arábigo está limitada principalmente al periodo de mayo a agosto. Por otro lado, en la Bahía de Bengala, independientemente de la estación de monzón, la cobertura de nubes es mayor a lo largo de todo el año. La nubosidad anual varía de 4.1 a 5.1 oktas sobre la Bahía de Bengala y de 1.5 a 3.7 oktas 


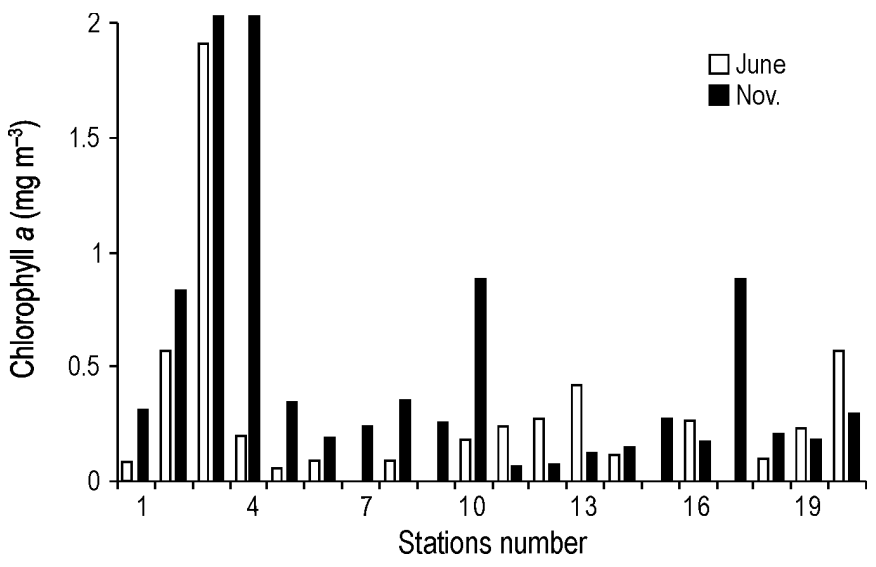

Figure 3. Representative example of pigment concentration data in June and November for the coastal region of the Indian Ocean, showing the trend of elevated pigment concentrations in the Arabian Sea (stations 1-5) compared with other regions of the Indian Ocean.

Figura 3. Ejemplo representativo de los datos de la concentración de pigmentos en junio y noviembre para la región costera del Océano Índico, mostrando la tendencia de concentraciones elevadas de pigmentos en el Mar Arábigo (estaciones 1-5) en comparación con otras regiones del Océano Índico.

variable due to varying cloud cover and the objectives of the Nimbus-7 satellite. A comparison of monthly mean image count data in coastal regions and in the open ocean (fig. 5) shows that the number of images in the coastal region is higher than in the open ocean region, and that the NE monsoon is relatively cloud-free compared with the SW monsoon. Image count data for the Arabian Sea, Bay of Bengal and equatorial region of the Indian Ocean (fig. 6) indicate that the Arabian Sea has the highest image count, followed by the Bay of Bengal, and then the equatorial region of the Indian Ocean. Cloud cover over the Arabian Sea, however, is largely confined to the period from May to August. In the Bay of Bengal, on the other hand, irrespective of the monsoon season, cloud cover is greater throughout the year. Annual cloud cover ranges from 4.1 to 5.1 oktas over the Bay of Bengal and from 1.5 to 3.7 oktas over the Arabian Sea (Indian Meteorological Department, 1976).

Next, a seasonal comparison was made of pigment concentrations in the open ocean regions of the Arabian Sea, Bay of Bengal and the equatorial Indian Ocean (fig. 7). In the Arabian Sea, the lowest and highest monthly average pigment concentrations were $0.31 \mathrm{mg} \mathrm{m}^{-3}$ in July and $1.87 \mathrm{mg} \mathrm{m}^{-3}$ in September, respectively; in the Bay of Bengal these values were $0.101 \mathrm{mg} \mathrm{m}^{-3}$ in June and $0.477 \mathrm{mg} \mathrm{m}^{-3}$ in March, respectively; and in the equatorial Indian Ocean these values were $0.055 \mathrm{mg} \mathrm{m}^{-3}$ in January and $0.119 \mathrm{mg} \mathrm{m}^{-3}$ in October, respectively. These analyses clearly reveal that the Arabian Sea sustains a greater biomass of phytoplankton than both the Bay of Bengal and the equatorial Indian Ocean.

The low pigment concentrations observed in the Bay of Bengal may result from light limitation due to cloud cover. The sobre el Mar Arábigo (Indian Meteorological Department, 1976).

Posteriormente, se realizó una comparación estacional de las concentraciones de pigmentos en las regiones oceánicas del Mar Arábigo, la Bahía de Bengala y el Océano Índico ecuatorial (fig. 7). En el Mar Arábigo los promedios mensuales menor y mayor de la concentración de pigmentos fueron $0.31 \mathrm{mg} \mathrm{m}^{-3}$ en julio y $1.87 \mathrm{mg} \mathrm{m}^{-3}$ en septiembre, respectivamente; en la Bahía de Bengala éstos fueron $0.101 \mathrm{mg} \mathrm{m}^{-3}$ en junio y $0.477 \mathrm{mg} \mathrm{m}^{-3}$ en marzo, respectivamente; y en el Océano Índico Ecuatorial fueron $0.055 \mathrm{mg} \mathrm{m}^{-3}$ en enero y $0.119 \mathrm{mg} \mathrm{m}^{-3}$ en octubre, respectivamente. Este análisis indica claramente que el Mar Arábigo sostiene una mayor biomasa fitoplanctónica que la Bahía de Bengala y el Océano Índico ecuatorial.

Las bajas concentraciones de pigmentos observadas en la Bahía de Bengala pueden ser el resultado de la limitación de luz debida a la cobertura de nubes. Los aspectos físicos de las surgencias en la costa somalí descritas por Schott (1983) indican que éstas normalmente se caracterizan por un sistema de dos giros. Las imágenes del CZCS de agosto y septiembre muestran que los sistemas de giros incrementaron las concentraciones de pigmentos en la costa. Mediante bombeo de Ekman, una extensiva surgencia hace aflorar nutrientes cerca de las costas somalíes y árabes (Swallow, 1984; Brock et al., 1990; Bauer et al., 1991). En el noroeste del Mar Arábigo se observaron concentraciones de pigmentos $<0.39 \mathrm{mg} \mathrm{m}^{-3}$ durante el monzón NE, en contraste con los valores de $6.61 \mathrm{mg} \mathrm{m}^{-3}$ registrados durante el monzón SW. La Corriente de Somalia fluye hacia el suroeste durante el monzón NE y hacia el noreste durante el monzón SW.

Los florecimientos de diatomeas son comunes en el Mar Arábigo (Nair et al., 1992) y su composición ha sido descrita por Sawant y Madhupratan (1996). Madhupratap et al. (2000) observaron un florecimiento denso y verde del alga marina Phaeocystis globosa en el Mar Arábigo central durante el monzón de verano. Qasim (1977) y Banse (1984) observaron productividad biológica asociada con el ciclo monzónico anual y demostraron que el Mar Arábigo era la región biológicamente más productiva del Índico. La productividad biológica del noroeste del Mar Arábigo ha sido atribuida a la presencia de elevadas concentraciones de nitrato, fosfato y silicato a profundidades someras en la zona eufótica (Ryther y Menzel, 1965; Ryther et al., 1966; Qasim, 1977, 1982). Las máximas concentraciones de clorofila $a$ y el mayor flujo del material particulado fuera de la zona fótica ocurren durante el monzón SW (Babenerd y Krey, 1974; Banse, 1987; Nair et al., 1989). Las concentraciones de pigmentos fitoplanctónicos fueron consistentemente bajas en el Océano Índico abierto debido al hundimiento convectivo y al giro levógiro. La imagen del CZCS muestra concentraciones muy bajas de pigmentos $\left(0.150-0.406 \mathrm{mg} \mathrm{m}^{-3}\right)$ en los meses de mayo y junio debidas a agua de baja salinidad que se acumula en el noreste de la Bahía 

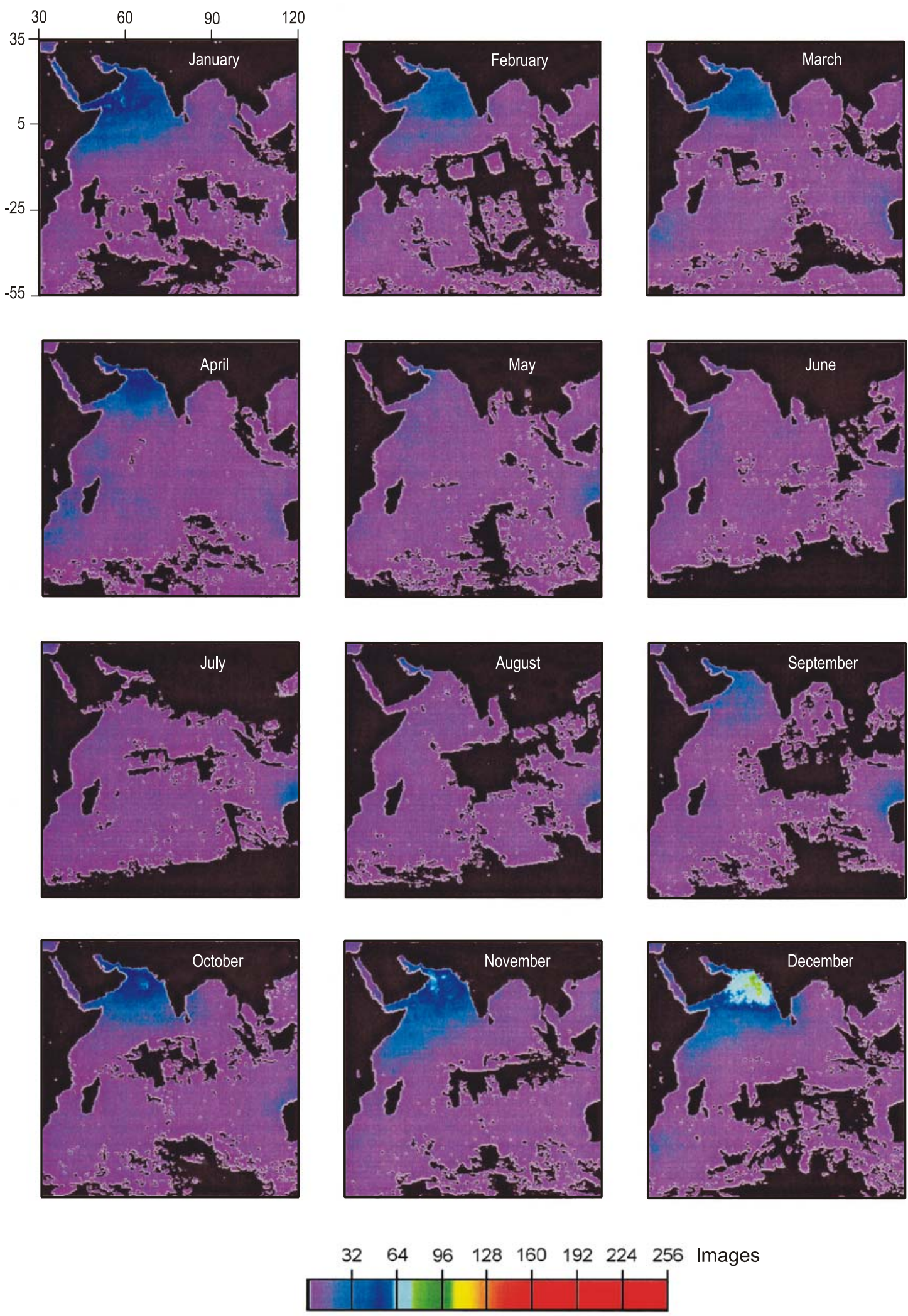

Figure 4. Time series for the 93-month period (October 1978 to June 1986) of the monthly mean distribution of the number of images in the Indian Ocean region. The color bar goes from pink, for a few counts, to red, for a large number of counts.

Figura 4. Serie de tiempo para el periodo de 93 meses (octubre de 1978 a junio de 1986) de la distribución media mensual del número de imágenes en la región del Océano Índico. La barra de color va de rosa, para unas cuantas imágenes, a rojo, para un gran número de imágenes. 


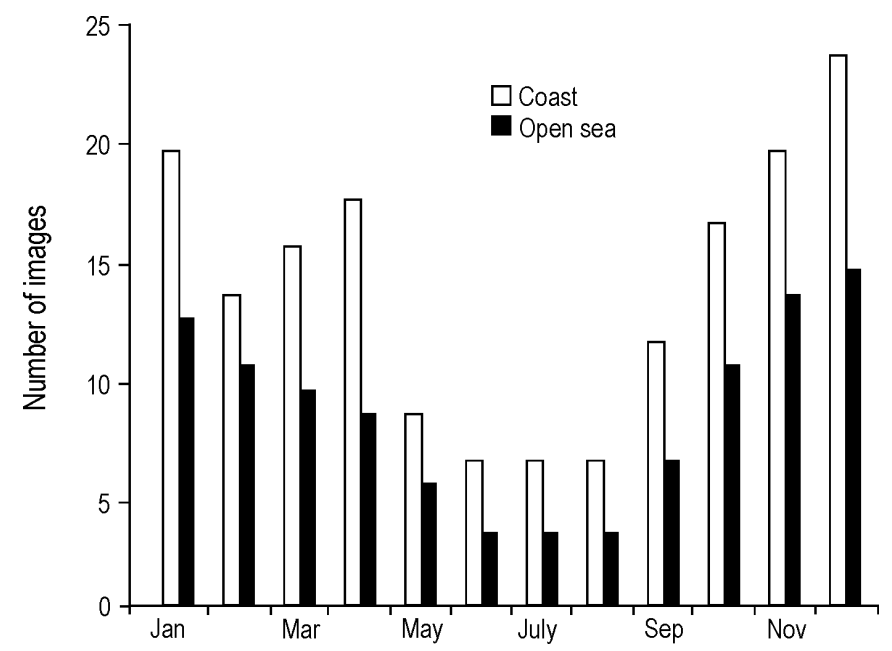

Figure 5. Time series for the 93-month period (October 1978 to June 1986) of the monthly seasonal mean variation of image count data in the coastal and open ocean regions of the Indian Ocean. The data were extracted from the 12 interpolated time series average images (fig. 4).

Figura 5. Serie de tiempo para el periodo de 93 meses (octubre de 1978 a junio de 1986) de la variación media mensual estacional del número de imágenes en las regiones costeras y oceánicas del Océano Índico. Los datos fueron obtenidos de la serie de tiempo del promedio de las 12 imágenes interpoladas (fig. 4).

physical aspects of the Somali upwelling described by Schott (1983) indicate that this upwelling is usually characterized by a two-gyre system. The CZCS images of August and September indicated that gyre systems increased pigment concentrations along the coast. Through Ekman pumping, extensive upwelling brings up nutrients along the Somali and Arabian coast (Swallow, 1984; Brock et al., 1990; Bauer et al., 1991). In the NW Arabian Sea, pigment concentrations $<0.39 \mathrm{mg} \mathrm{m}^{-3}$ were observed during the NE monsoon, in contrast to values of $6.61 \mathrm{mg} \mathrm{m}^{-3}$ during the $\mathrm{SW}$ monsoon. The Somali current flows toward the SW during the NE monsoon and toward the NE during the SW monsoon.

Diatom blooms are common in the Arabian Sea (Nair et al., 1992) and their composition has been reported by Sawant and Madhupratan (1996). A dense, green bloom of the marine prymnesiophycean, Phaeocystis globosa, was observed in the central Arabian Sea (Madhupratap et al., 2000) during the summer monsoon. Qasim (1977) and Banse (1984) observed biological productivity associated with the annual monsoon cycle, and showed that the Arabian Sea was the most biologically productive region of the Indian Ocean. The biological productivity of the NW Arabian Sea has been attributed to the presence of high concentrations of nitrate, phosphate and silicate at shallow depths within the euphotic zone (Ryther and Menzel, 1965; Ryther et al., 1966; Qasim, 1977, 1982). The maximum chlorophyll $a$ concentrations and highest particulate matter flux out of the photic zone occur during the SW monsoon (Babenerd and Krey, 1974; Banse, 1987; Nair et al., 1989). Phytoplankton pigment concentrations were

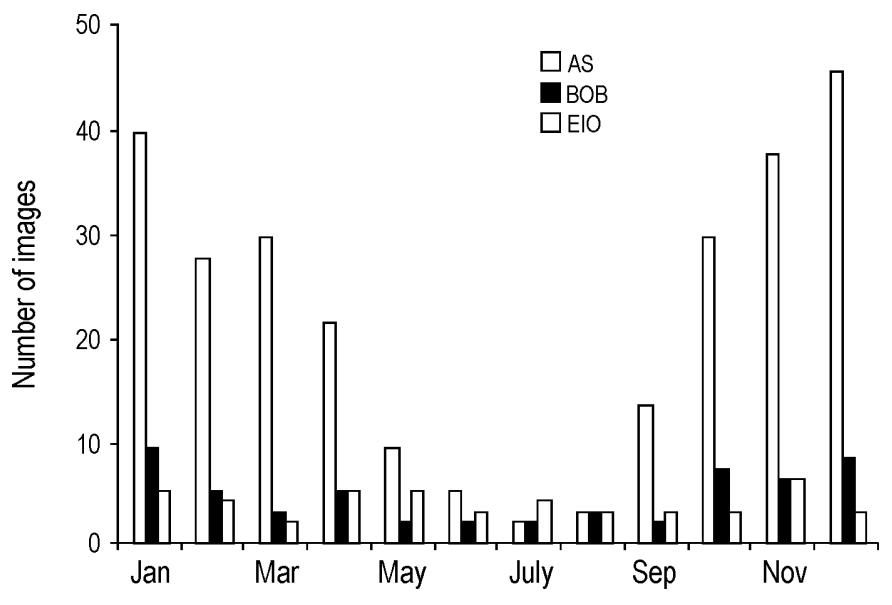

Figure 6. Time series of the seasonal variation of image count data in the Arabian Sea (AS), Bay of Bengal (BOB) and the equatorial Indian Ocean region (EIO). The data were extracted from the 12 interpolated monthly time series images (fig. 4).

Figura 6. Serie de tiempo de la variación estacional del número de imágenes en el Mar Arábigo (AS), la Bahía de Bengala (BOB) y la región del Océano Índico Ecuatorial (EIO). Los datos fueron extraidos de la serie de tiempo del promedio de las 12 imágenes interpoladas (fig. 4).

de Bengala y es transportada al sur del Mar Arábigo (Donguy y Meyers, 1996). En la Bahía de Bengala, las concentraciones de pigmentos fitoplanctónicos oscilaron entre 0.150 y $0.406 \mathrm{mg} \mathrm{m}^{-3}$ de noviembre a abril.

Los pigmentos fitoplanctónicos variaron considerablemente debido a las surgencias y a la mezcla convectiva de invierno en el noroeste del Mar Arábigo, y fueron menores en el mar abierto, donde no se presentan estos efectos.

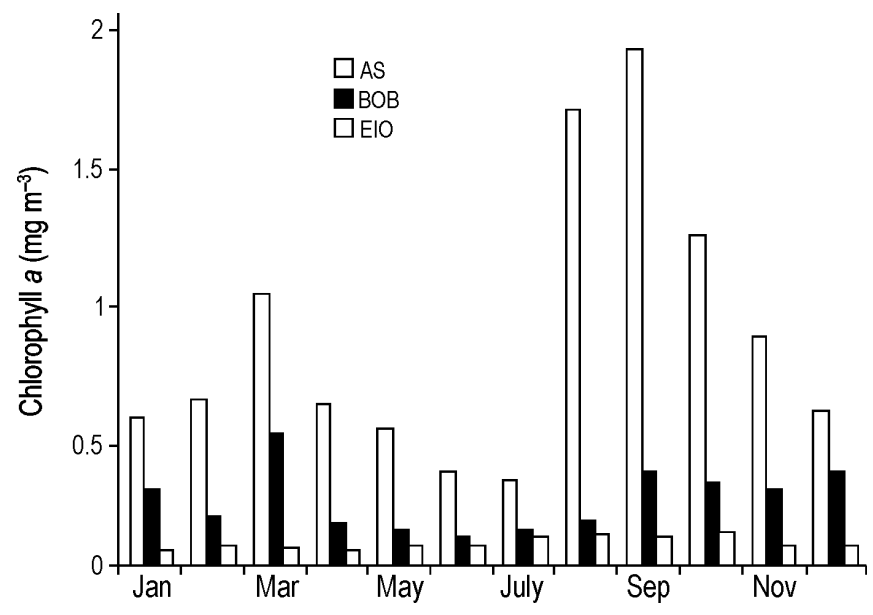

Figure 7. Time series of the seasonal variation of phytoplankton pigment concentrations in the Arabian Sea (AS), Bay of Bengal (BOB) and the equatorial Indian Ocean region (EIO). The data were extracted from the 12 interpolated monthly time series images (fig. 2).

Figura 7. Serie de tiempo de la variación estacional de las concentraciones de pigmentos fitoplanctónicos en el Mar Arábigo (AS), la Bahía de Bengala (BOB) y la región del Océano Índico Ecuatorial (EIO). Los datos fueron extraidos de la serie de tiempo del promedio de las 12 imágenes interpoladas (fig. 2). 
consistently low in the open Indian Ocean due to the downwelling and anti-clockwise gyre. The CZCS image shows very low pigment concentration $\left(0.150-0.406 \mathrm{mg} \mathrm{m}^{-3}\right)$ in the months of May and June as a result of low salinity water, which accumulates in the northeastern Bay of Bengal, being carried into the southern Arabian Sea (Donguy and Meyers, 1996). In the Bay of Bengal phytoplankton pigment concentrations ranged from 0.150 to $0.406 \mathrm{mg} \mathrm{m}^{-3}$ from November to April.

Phytoplankton pigments were very variable due to upwelling and winter convective mixing in the northwestern Arabian Sea and low in the open ocean where none of these effects occurred.

\section{Acknowledgements}

Funding for this research was provided by the Japanese Ministry of Education, Sports and Culture, and by an award from the Flinders University of South Australia. This work was supported by an Australian Research Council grant to Jim G. Mitchell. The author gratefully acknowledges Toshiro Saino (Nagoya University, Japan) for his valuable comments and suggestions for use of the PC-SEAPAK software, and thanks Scoresby Shepherd (SARDI, Australia) and three anonymous reviewers for valuable and encouraging comments on the manuscript.

\section{References}

Babenerd, B. and Krey, J. (1974). Indian Ocean: Collected data on primary productivity, phytoplankton pigments and some related factors. University Press, Kiel, West Germany, 521 pp.

Banse, K. (1984). Overview of the hydrology and associated biological phenomenon in the Arabian Sea, off Pakistan. In: B.U. Haq and J.D. Milliman (eds.), Marine Geology and Oceanography of Arabian Sea and Coastal Pakistan. Van Nostrand, Reinhold Co., New York.

Banse, K. (1987). Seasonality of phytoplankton chlorophyll in the central and northern Arabian Sea. Deep-Sea Res., 34: 713-723.

Banse, K. and McClain, C. (1986). Winter blooms of phytoplankton in the Arabian Sea as observed by the Coastal Zone Colour Scanner. Mar. Ecol. Prog. Ser., 34: 201-211.

Banse, K. and English, D.C. (1994). Seasonality of Coastal Zone Colour Scanner phytoplankton pigment in the offshore oceans. J. Geophys. Res., 99: 7323-7345.

Banse, K. and English, D.C. (2000) Geographical differences in seasonality of CZCS-derived phytoplankton pigment in the Arabian Sea for 1978-1986. Deep Sea Res., 47(2): 1623-1677.

Barnard, A.H., Stegmann, P.M. and Yoder, J.A. (1997). Seasonal surface ocean variability in the South Atlantic Bight derived from CZCS and AVHRR imagery. Cont. Shelf Res., 17: 1181-1206.

Bauer, S.G., Hitchock L. and Olson, D.B. (1991). Influence of monsoonally forced Ekman dynamics upon surface layer depth and plankton biomass distribution in the Arabian Sea. Deep-Sea Res., 38: 531-553.

Brock, J.C., McClain, C.R. and Hay, W.W. (1990). Southwest monsoon biological variability in the northwest Arabian Sea. EOS Trans. Am. Geophys. Union, 71: 532.

\section{Agradecimientos}

Este trabajo fue financiado por el Ministerio de Educación, Deportes y Cultura de Japón y una aportación económica de la Universidad de Flinders del Sur de Australia, así como por una beca del Consejo de Investigación Australiano a Jim G. Mitchell. El autor agradece a Toshiro Saino (Universidad de Nagoya, Japón) sus valiosos comentarios y sugerencias para el uso de la paquetería PC-SEAPAK, y a Scoresby Shepherd (SARDI, Australia) y tres revisores anónimos sus valiosos y alentadores comentarios al manuscrito.

Traducido al español por Christine Harris.

Chauhan, P., Nagur, C.R.C., Mohan, M., Nayak, S.R. and Navalgung, R.R. (2001). Surface chlorophyll-a distribution in Arabian Sea and Bay of Bengal using IRS-P4 ocean colour monitoring satellite data. Curr. Sci., 80: 127-129.

Darzi, M., Chen, J., Firestone, K.J. and McClain, C.R. (1989). SEAPAK: A satellite image analysis system for oceanographic research. Proc. Fifth International Conf. on Interactive and Information Processing systems for Meteorology, Hydrography, and Oceanography. American Meteorological Society, Anaheim, Jan. 30-Feb. 3, 1989, pp. 26-32.

Donguy, J. and Meyers, G. (1996). Seasonal variations of sea-surface salinity and temperature in the tropical Indian Ocean. Deep-Sea Res., 43: 117-138.

Esaias, W.E. (1980). Remote sensing of oceanic phytoplankton: Present capabilities and future goals. In: P.G. Falowski (eds.), Primary Productivity in the Sea. Plenum, New York, pp. 321-337.

Feldman, G., Kuring, N., Esaias, W., McClain, C., Elrod, J., Maynard, N., Endres, D., Evans, R., Brown, J., Walsh, S., Carle, M. and Podesta, G. (1989). Ocean colour: Availability of the global data. EOS Trans. Am. Geophys. Union, 70: 634-641.

Gordon, H.R. and Morel, A.Y. (1983). Remote Assessment of Ocean Color for Interpretation of Satellite Visible Imagery: A Review. Springer-Verlag, New York.

Gordon, H.R., Clark, D.K., Mueller, J.L. and Hovis, W.A. (1980). Phytoplankton pigments from the NIMBUS-7 Coastal Zone Color Scanner: Comparisons with surface measurements. Science, 210: 63-66.

Hovis, W.A., Clark, D.K., Anderson, F., Austin, R.W., Wilson, W.H., Baker, E.T., Ball, D., Gordon, H.R., Mueller, J.L., El-Sayed, S.Z., Sturm, B., Wrigley, R.C. and Yentsch, C.S. (1980). NIMBUS-7 Coastal Zone Color Scanner: System description and initial imagery. Science, 212: 60-63.

Indian Meteorological Department (1976). Marine climatological summaries for the Indian Ocean north of $15^{\circ}$ South between $20^{\circ}$ and $100^{\circ}$ East. The Controller of Publication, Department of Publication, Government of India, Delhi, 442 pp.

Krey, J. and Babenered, B. (1976). Phytoplankton Production. International Oceanographic Commission, Paris, 70 pp.

Madhupratap, M., Sawant, S. and Gaunas, M. (2000). A first report on a bloom of marine prymnesiophycean, Phaeocystis globosa, from the Arabian Sea. Oceanol. Acta, 23: 83-90.

McClain, C.R., Esaias, W.E., Feldman, G.C., Elrod, J. Eudres, D., Firestone, J., Darzi, M., Evans, R. and Brown, J. (1990). Physical and biological processes in the North Atlantic during the EGGE year. J. Geophys. Res., 95: 18027-18048.

Nair, R.R., Ittekkot, V., Manganini, S.J., Ramaswamy, V., Haake, B., Degens, E.T., Desai, B.N. and Honjo, S. (1989). Increased 
particle flux to the deep ocean and related monsoons. Nature, 338: 749-751.

Nair, S.R.S., Devassy, V.P. and Madhupratap, M. (1992). Blooms of phytoplankton along the west coast of India associated with nutrient enrichment and the response of zooplankton. Sci. Total Environ. Suppl. 1992, Elsevier, pp. 819-828.

Platt, T. and Sathyendranath, S. (1988). Oceanic primary production: Estimation by remote sensing at local and regional scales. Science, 241: 1613-1620.

Prasanna-Kumar, S. and Prasad, T.G. (1996). Winter cooling in the northern Arabian Sea. Curr. Sci., 71: 834-841.

Qasim, S.Z. (1977). Biological productivity of the Indian Ocean. Indian J. Mar. Sci., 6: 122-137.

Qasim, S.Z. (1978). Chlorophyll $a$ in the Indian Ocean. Indian J. Mar. Sci., 7: 258-262.

Qasim, S.Z. (1982.) Oceanography of the northern Arabian Sea. Deep-Sea Res., 29: 1041-1068.

Ryther, J.H. and Menzel, D.W. (1965). Production, composition and distribution of organic matter in the western Arabian Sea. DeepSea Res., 12: 199-209.

Ryther, J.H., Hall, J.R., Pease, A.K., Bakun, A. and Jones, M.M. (1966). Primary organic production in relation to the chemistry and hydrography of the western Indian Ocean. Limnol. Oceanogr., 11: 371-380.

Sathyendranath, S., Platt, T., Horne, E.P.W., Harrison, W.G., Ulloa, S., Outerbridge, R. and Hoepffner, N. (1991). Estimation of new production in the ocean by compound remote sensing. Nature, 353: $129-133$.

Sawant, S. and Madhupratan, M. (1996). Seasonality and composition of phytoplankton in the Arabian Sea. Curr. Sci., 71: 869-873.

Schott, F. (1983). Monsoon response of the Somali current and associated upwelling. Prog. Oceanogr., 112: 357-381.

Swallow J.C.(1984). Some aspects of the physical oceanography of the Indian Ocean. Deep-Sea Res., 31: 639-650.

UNESCO (1988). River inputs to the ocean systems: Status and recommendations for research. Unesco Technical Papers in Marine Science, No. 55, Final Report of the SCOR Working Group 46, Paris, 25 pp.

Wyrtki, K. (1971). Oceanographic Atlas of the International Indian Ocean Expedition. National Science Foundation, Washington, DC, $531 \mathrm{pp}$.

Wyrtki, K. (1973). Physical oceanography of the Indian Ocean. In: B. Zeitzschel (ed.), The Biology of the Indian Ocean. SpringerVerlag, New York, pp. 18-36.

Yentsch, C.S. (1983). Remote sensing of biological substances. In: A.P. Cracknell (ed.), Remote Sensing Application in Marine Science and Technology. Reidel, pp. 267-297.

Yoder, J.A., McClain, C.R., Feldman, G.C. and Esaias, W.E. (1993). Annual cycles of phytoplankton chlorophyll concentrations in the global ocean: A satellite view. Global Biogeochem. Cycles, 7: 181-193. 